\title{
Effects of supplemental dietary energy on leucine metabolism in sheep*
}

\author{
BY STEVEN NISSEN AND PIOTR OSTASZEWSKI† \\ Department of Animal Science, Iowa State University, Ames, Iowa 50011, USA
}

(Received 4 June 1985 - Accepted 24 June 1985)

1. Mixed-breed wethers (40-50 kg), 9 months old, were maintained on high-energy (HED) and low-energy (LED) diets for 2 weeks.

2. After a $15 \mathrm{~h}$ fast, a primed-dose constant infusion of $\mathrm{L}-\left[\mathrm{U}-{ }^{14} \mathrm{C}\right]$ leucine and $\alpha-\left[4,5-{ }^{3} \mathrm{H}\right] \mathrm{ketoisocaproate}$ (KIC) was given.

3. After $2 \mathrm{~h}$, plasma samples were taken and plasma-specific radioactivities of ${ }^{14} \mathrm{C}$ - and ${ }^{3} \mathrm{H}$-labelled leucine and $\mathrm{KIC}$ were measured and analysed by using an open two-pool model.

4. Less than $20 \%$ of the total leucine-C entering the circulation was converted to the KIC pool, and $42 \%$ of the KIC was converted back to the leucine pool; transamination of the leucine to KIC and reamination of KIC to leucine was much less than in other species.

5. Additional dietary energy resulted in a decrease in tissue protein synthesis, leucine oxidation and interconversion of leucine and KIC. Total leucine-C entry was also lower in sheep given HED, which was most likely due to a suppression of endogenous proteolysis.

6. Plasma glucagon concentration was significantly higher $(P<0.05)$ in sheep given LED compared with those given HED. The concentration of glucagon was closely correlated in all treatments with the leucine-C entry (proteolysis + absorbed leucine) and also with KIC-C exit (oxidation).

Availability of energy in the form of high-energy phosphates can potentially affect several steps in leucine metabolism; ATP and GTP are necessary for protein synthesis (Kramer \& Hardesty, 1980) and proteolysis (Dean, 1980), while NAD: NADH is known to have an important regulatory function in proteolysis (Fagan \& Tischler, 1982) as well as in controlling decarboxylation of $\alpha$-ketoisocaproate (KIC) (Odyssey, 1980). In addition, the transamination reaction leucine $\rightleftharpoons \mathrm{KIC}$, although not directly consuming energy, does depend on the concentrations of other intermediates (glutamate, $\alpha$-ketoglutarate) which are regulated by energy availability. Whether the metabolic differences in energy substrates in ruminants (volatile fatty acid-based energy metabolism) result in altered leucine metabolism is unknown.

Leucine belongs to a distinct class of amino acids (branched-chain amino acids) whose degradation occurs initially at extrahepatic sites (Goldberg \& Chang, 1978; Frick \& Goodman, 1979; Lindsay, 1980). These amino acids seem to share enzymes needed for their initial transamination (Ichihara et al. 1973; Veerkamp \& Wagenmakers, 1981) and subsequent decarboxylation of their $\alpha$-keto analogs (Hughes \& Halestrap, 1981; Gillim et al. 1983).

Several laboratories have provided direct evidence that interconversion of circulating leucine and KIC is extensive, e.g. in pigs (Helland, 1984), dogs (Nissen \& Haymond, 1981), rats (Hutson et al. 1978) and humans (Matthews et al. 1981). However, little is known about leucine-KIC interconversion in ruminants. Studies in fasting sheep (Teleni et al. 1983) demonstrated that approximately $30 \%$ of the amino- $\mathrm{N}$ in the circulating alanine is derived from branched-chain amino acids. In similar studies performed in man (Haymond \& Miles,

* Journal Paper no. J-11595 of the Iowa Agriculture and Home Economics Experiment Station, Ames, Iowa, Project No. 2614.

† Present address: Department of Animal Physiology, Faculty of Veterinary Medicine, Nowoursynowska 166, 02-766 Warsaw, Poland. 
1982), up to $60 \%$ of the amino- $\mathrm{N}$ released as alanine is related to the breakdown of branched-chain amino acids. Lindsay (1980) proposed that muscle oxidation of the branched-chain amino acids occurs to a lesser extent in ruminants. These findings suggest that catabolism and transamination of branched-chain amino acids is quantitatively much less in sheep than in human muscle.

The purpose of the present experiment was to study the kinetics of leucine metabolism in sheep and to evaluate the effects of supplemental energy intake on the regulation of leucine kinetics in vivo.

\section{MATERIALS AND METHODS}

\section{Animals and diets}

Six 9-month-old, mixed-breed wethers (40-50 kg) were used in the experiment. Sheep were placed in metabolism cages and were adjusted to the experimental diets for 2 weeks (Table 1). Three animals were fed on a low-energy diet (LED) at a maintenance level of intake, and the remaining three were fed on a diet which was $80 \%$ higher in energy (HED). Food was offered twice daily. After period 1 of the experiment was completed, the animals were switched to the opposite diet (period 2) for an additional 2 weeks. Between the first and second periods one animal was removed from the test due to illness.

At least $24 \mathrm{~h}$ before isotope infusions, two catheters were inserted, one in the right jugular vein for isotope infusion, and one in the left jugular vein for blood sampling. Food was withheld from animals for $15 \mathrm{~h}$ preceding isotope infusion, but the animals were allowed free access to water. It was assumed that $15 \mathrm{~h}$ of fasting would not reduce microbial protein absorption to zero. However, total protein absorption would probably be less than in the fed state since rumen by-pass protein would not contribute greatly to amino acid absorption $15 \mathrm{~h}$ after feeding.

Isotope infusions were initiated between 08.00 and 10.00 hours. A primed dose $(2 \mathrm{ml})$ constant infusion $(0.1 \mathrm{ml} / \mathrm{min})$ of isotopes (approximately $0.6 \mu \mathrm{Ci} \mathrm{L}-\left[\mathrm{U}-{ }^{14} \mathrm{C}\right]$ leucine $/ \mathrm{min}$ and $1.8 \mu \mathrm{Ci}\left[4,5-\alpha^{-}{ }^{3} \mathrm{H}\right] \mathrm{KIC} / \mathrm{min}$ ) was accomplished using a syringe pump (Harvard Apparatus). After a $2 \mathrm{~h}$ equilibration period to reach steady state, blood was taken over the next hour at 15 -min intervals.

\section{Chemicals}

L- $\left[4,5-{ }^{3} \mathrm{H}\right]$ leucine $(70 \mathrm{Ci} / \mathrm{mmol})$ and $\mathrm{L}-\left[\mathrm{U}-{ }^{14} \mathrm{C}\right]$ leucine $(350 \mathrm{mCi} / \mathrm{mmol})$ were obtained from Amersham International plc, Amersham, Bucks, UK. $\alpha-\left[4,5-{ }^{3} \mathrm{H}\right] \mathrm{KIC}$ was prepared from L-[4,5- $\left.{ }^{3} \mathrm{H}\right]$ leucine by the method of Rudiger et al. (1972). Liquid scintillation cocktail was obtained from Beckman, Palo Alto, CA, and high-performance liquid chromatography (HPLC) grade solvents were obtained from Fisher Chemical, Pittsburgh, PA. Ovine serum albumin and chemicals for free fatty acids (FFA) determination were obtained from Sigma Chemical, St Louis, MO. Growth hormone was purified according to the method of Wallace \& Ferguson (1963). Glucagon antibodies (30K) were purchased from Dr Unger, Dallas, TX.

\section{Chemical analyses}

Plasma leucine and KIC concentrations were determined by a modification of an HPLC procedure as described previously (Nissen et al. 1982). In this procedure, the acetonitrilebuffer mixture was replaced by a methanol-buffer mixture $(25: 75, \mathrm{v} / \mathrm{v})$. This change was necessary to remove a peak present in sheep plasma that co-eluted with KIC.

FFA (Shimizu et al. 1979), glucagon (Faloona \& Unger, 1974), insulin (Trenkle, 1970), growth hormone (Trenkle, 1976) and glucose (Trinder, 1969) were determined.

Measurements of leucine and KIC specific activities and concentrations of leucine and 
Table 1. Details of animals and composition of experimental diets

\begin{tabular}{|c|c|c|}
\hline & \multicolumn{2}{|c|}{ Diet } \\
\hline & High energy & Low energy \\
\hline No. of animals & 6 & 5 \\
\hline Body-wt $(\mathrm{kg})$ & 46.4 (SE 3.7) & $45 \cdot 6(\mathrm{SE} 4 \cdot 5)$ \\
\hline \multicolumn{3}{|l|}{ Diet consumed* $(\mathrm{g})$} \\
\hline Ground maize & 472 & 476 \\
\hline Maize-gluten meal & 52 & 53 \\
\hline Soya-bean meal & 39 & 40 \\
\hline Molasses & 93 & 94 \\
\hline Mineral-vitamin premix & 6 & 6 \\
\hline Maize starch & 326 & - \\
\hline Total & 988 & 669 \\
\hline Metabolizable energy $(\mathrm{MJ} / \mathrm{kg}$ ) & $9 \cdot 54$ & $5 \cdot 27$ \\
\hline
\end{tabular}

* Daily intake of feed ingredient per animal.

KIC were measured by using HPLC techniques (Nissen \& Haymond, 1981). Radioactivity in both leucine and $\mathrm{KIC}\left({ }^{14} \mathrm{C}\right.$ and $\left.{ }^{3} \mathrm{H}\right)$ was measured simultaneously in a dual-channel liquid-scintillation counter (Beckman model 8000 ) by using external quench-correction techniques.

\section{Whole-body flux calculations}

The six measurements $\left(\left[{ }^{14} \mathrm{C}\right]\right.$ leucine and $\left[{ }^{3} \mathrm{H}\right] \mathrm{KIC}$ infusion rates and ${ }^{14} \mathrm{C}$ and ${ }^{3} \mathrm{H}$ specific radioactivities of both leucine and KIC) were substituted into the six simultaneous equations described by Nissen \& Haymond (1981). From these equations, estimates of leucine and KIC interconversions, KIC oxidation, and leucine entry and exit were derived. Total leucine-C-skeleton flux is defined as the sum of new C-skeleton entry into both the leucine and KIC pools. All the values are expressed as means with their standard errors. Statistical differences in all measured factors were evaluated by using ANOVA.

\section{RESULTS}

Plasma glucagon concentrations (Table 2) were 111 (SE 17) ng/l in sheep fed on HED and significantly increased to 137 (SE 14) ng/l in animals receiving LED. Plasma insulin (Table 2) concentration was higher in the animals fed on HED, but this difference was not statistically significant. Growth hormone concentration (Table 2) was 6.01 (SE 1.45) and 9.26 (SE 1.59) $\mathrm{ng} / \mathrm{l}$ in sheep fed on HED and LED respectively.

Mean plasma leucine concentrations (Table 2) were 108 (SE 20) in LED- and 148 (SE 15) $\mu \mathrm{mol} / 1$ in HED-fed animals $(P<0 \cdot 01)$. KIC and glucose concentrations were not significantly different between the groups. FFA concentrations in the LED-fed animals were nearly twice that of HED-fed animals at 511 (SE 72) and 272 (SE 74) $\mu \mathrm{mol} / \mathrm{l}$ respectively.

Fig. 1 presents an open two-pool reversible model of leucine and KIC metabolism. Leucine-C entry into the system $\left(F_{L O}\right)$ decreased from 2.88 (SE 0.28$)$ to 1.81 (sE 0.36$) \mu \mathrm{mol} / \mathrm{kg}$ per min $(P<0 \cdot 05)$ with supplemental dietary energy (HED). KIC-C entry $\left(F_{a o}\right)$ in LEDand HED-fed animals was very low, 0.03 (SE 0.7) and 0.02 (SE 0.01$) \mu \mathrm{mol} / \mathrm{kg}$ per min respectively. Conversion of leucine to $\mathrm{KIC}\left(F_{a L}\right)$ was $0.58(\mathrm{SE} 0.15) \mu \mathrm{mol} / \mathrm{kg}$ per min in sheep fed on LED and decreased to 0.30 (SE 0.09 ) $\mu \mathrm{mol} / \mathrm{kg}$ per min with supplemental dietary energy (HED $v$. LED; $P<0.05$ ). 
Table 2. Plasma metabolites and hormone concentrations in sheep fed on high-and low-energy diets*

(Mean values with their standard errors)

\begin{tabular}{|c|c|c|c|c|c|}
\hline \multirow[b]{3}{*}{ Metabolite } & \multicolumn{4}{|c|}{ Diet } & \multirow{3}{*}{$\begin{array}{c}\text { Statistical } \\
\text { significance of } \\
\text { difference: } P<\end{array}$} \\
\hline & \multicolumn{2}{|c|}{ High energy } & \multicolumn{2}{|c|}{ Low energy } & \\
\hline & Mean & SE & Mean & $\mathrm{SE}$ & \\
\hline Glucagon (ng/1) & 111 & 17 & 137 & 14 & 0.05 \\
\hline Insulin (mU/l) & $29 \cdot 76$ & 8.88 & $26 \cdot 16$ & $5 \cdot 28$ & NS \\
\hline Growth hormone $(\mu \mathrm{g} / \mathrm{l})$ & 6.01 & 1.45 & $9 \cdot 26$ & 1.59 & 0.05 \\
\hline Leucine $(\mu \mathrm{mol} / \mathrm{l})$ & 148 & 15 & 108 & 20 & 0.01 \\
\hline $\mathrm{KIC}(\mu \mathrm{mol} / \mathrm{l})$ & $15 \cdot 7$ & $2 \cdot 8$ & $18 \cdot 4$ & $3 \cdot 5$ & NS \\
\hline Glucose $(\mathrm{mmol} / \mathrm{l})$ & 3.66 & 0.29 & $3 \cdot 17$ & 0.57 & NS \\
\hline Free fatty acids $(\mu \mathrm{mol} / \mathrm{l})$ & 272 & 74 & 511 & 72 & 0.01 \\
\hline
\end{tabular}

KIC, $\alpha$-ketoisocaproate; NS, not significant.

* For details, see p. 706 and Table 1.

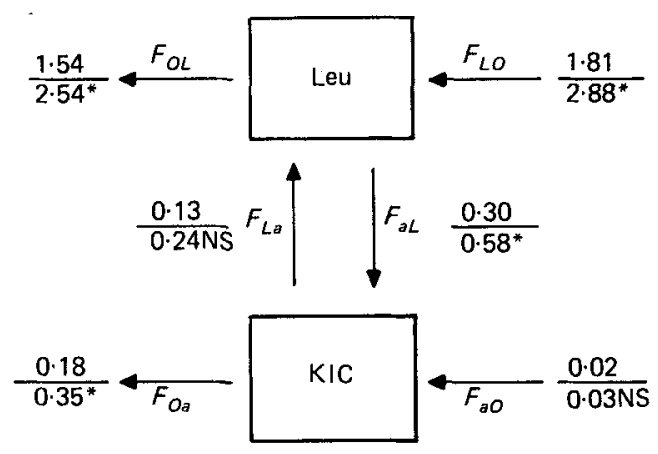

Fig. 1. Model for leucine (leu) and $\alpha$-ketoisocaproate (KIC) metabolism in sheep fed on a high-energy diet (values above the line) or a low-energy diet (values below the line). The mathematical representation $F_{i j}$ indicates transfer to pool $i$ (leu or KIC) from pool $j$ (leu or KIC) (all values $\mu \mathrm{mol} / \mathrm{kg}$ per min). Differences between the high- and low-energy diets were statistically significant: ${ }^{*} P<0.05$. NS, not significant. Leu-carbon entry $=F_{L O}$, KIC-C entry $=F_{a O}$, leu $\rightarrow \mathrm{KIC}=F_{a L}, \mathrm{KIC} \rightarrow$ leu $=F_{L a}$, leu-C exit $=F_{O L}$, KIC-C exit $=F_{O a}$.

Conversion of KIC to leucine $\left(F_{L a}\right)$ was 0.13 (SE 0.05) and 0.24 (SE 0.05) $\mu \mathrm{mol} / \mathrm{kg}$ per min in animals fed on HED and LED respectively. Supplemental energy in the diet decreased irreversible loss of circulating KIC $\left(F_{O a}\right)$ by $50 \%$ from 0.35 (SE 0.07 ) to 0.18 (SE 0.05$) \mu \mathrm{mol} / \mathrm{kg}$ per min respectively $(P<0.05)$ as well as leucine-C exit $\left(F_{O L}\right)$ from $2.54($ SE 0.26$)$ to 1.54 (SE 0.37$) \mu \mathrm{mol} / \mathrm{kg}$ per $\min (P<0.05)$.

Fig. 2 presents the correlations between plasma glucagon concentration and leucine-C entry $\left(F_{L O}\right)$. The overall correlation of 0.75 for all eleven studies was statistically significant $(P<0.05)$. In Fig. 2, the correlation $(r 0.84)$ between plasma glucagon concentration and KIC-C exit $\left(F_{O a}\right)$ was also significant $(P<0.05)$. 

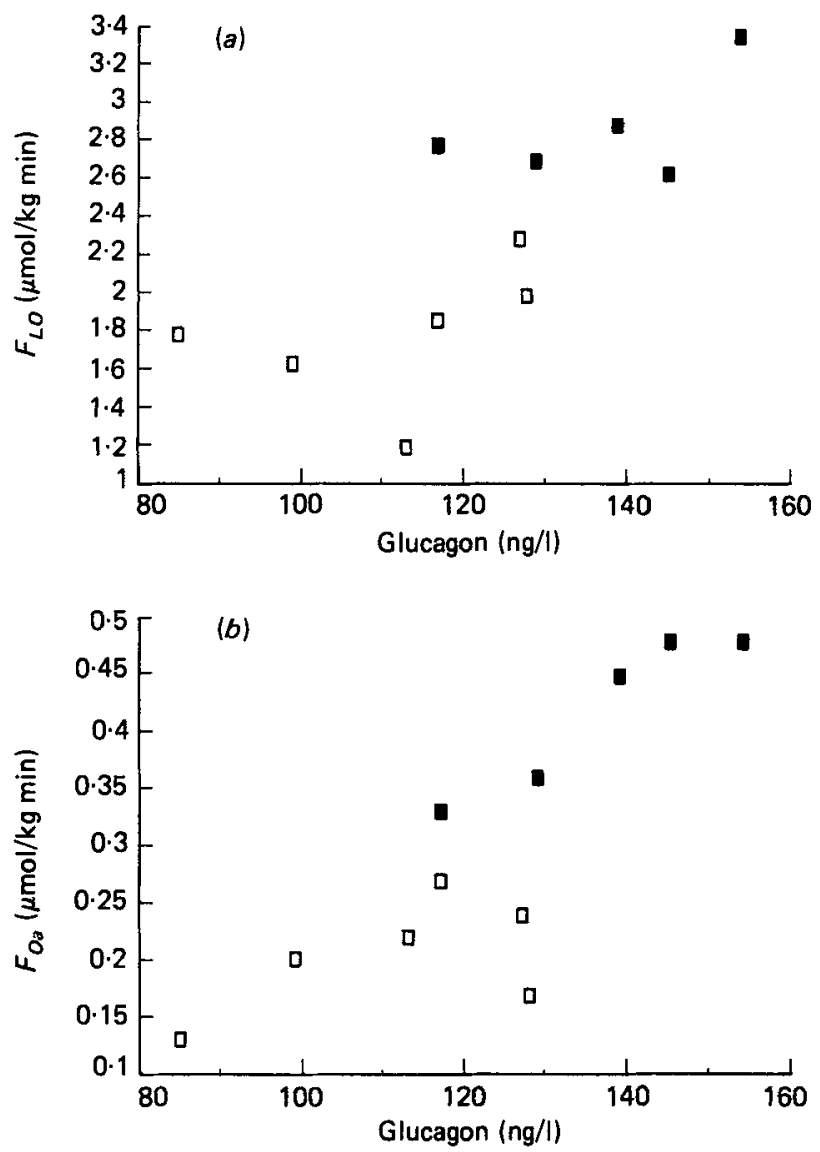

Fig. 2. (a) Correlation between plasma glucagon concentration and total $\alpha$-ketoisocaproate oxidation $\left(F_{O a}\right)(r 0.84, P<0.05)$ and $(b)$, correlation between plasma glucagon concentration and leucine-carbon entry $\left(F_{L O}\right)(r 0 \cdot 84, P<0.05)$ in sheep fed on high-energy $(\square)$ and low-energy $(\square)$ diets. Points represent values for individual animals.

\section{DISCUSSION}

Analysis of leucine and KIC kinetics during the simultaneous infusion of $\left[{ }^{14} \mathrm{C}\right]$ leucine and $\left[{ }^{3} \mathrm{H}\right] \mathrm{KIC}$ indicates that the interconversion of the $\mathrm{C}$ skeletons of circulating leucine and $\mathrm{KIC}$ in conscious sheep is lower than in other species. Approximately $20 \%$ of the total leucine-C entering the circulation was converted to KIC $\left(\left[F_{a L}+F_{a O}\right] / F_{L O}\right)$. This is in contrast with the results obtained from other species (Table 3 ) where, for example, in dogs, more than $80 \%$ of the total leucine-C entering the circulation was converted to KIC (Nissen \& Haymond, 1981). In addition, the percentage of KIC reaminated to leucine is also much lower than in other species (Table 3). This low rate of leucine-KIC interconversion may help explain the high output of glycine in ruminant muscle compared with non-ruminants (Lindsay et al. 1977), since keto acids are thought to inhibit glycine oxidation and promote its synthesis (O'Brien, 1978).

The reasons for the lower rates of leucine-KIC interconversion are not clear from the present studies. Leucine and KIC concentrations do not seem greatly different from those of other species (Nissen \& Haymond, 1981; Helland, 1984). Thus the $\alpha$-ketoglutarate or glutamate concentrations must be altered, or the activity of the transaminase must be very 
Table 3. Relative values of leucine- $\alpha$-ketoisocaproate $(K I C)$ interconversion in different species in a postabsorptive state

\begin{tabular}{llccl}
\hline \hline & $\begin{array}{c}\text { Percentage } \\
\text { of leucine } \\
\text { converted } \\
\text { to KIC }\end{array}$ & $\begin{array}{c}\text { Percentage } \\
\text { of KIC } \\
\text { reaminated } \\
\text { to leucine }\end{array}$ & \multicolumn{1}{c}{ Reference } \\
\hline Species & Human & $59 \cdot 2$ & $91 \cdot 1$ & Matthews et al. (1981) \\
& $62 \cdot 2$ & $61 \cdot 1$ & Helland (1984) \\
Pig & $82 \cdot 1$ & $66 \cdot 5$ & Nissen \& Haymond (1981) \\
Dog & $18 \cdot 5$ & $42 \cdot 0$ & Present study \\
\hline
\end{tabular}

low. Recent studies by Busboom et al. (1984) indicate that transaminase activity in ruminants is five- to tenfold less than in non-ruminant tissues, thus supporting the concept of limiting transaminase activity in ruminants.

Output of the branched-chain amino acids from ruminant muscle (Bell et al. 1975; Ballard et al. 1976) is greater than that from muscle of simple-stomached animals. These observations also suggest that the utilization of branched-chain amino acids occurs to a much lesser extent in ruminant muscle. Studies in vitro (Coward, 1979) have demonstrated that the addition of leucine to perfused sheep diaphragm has no effect on alanine output. This is in contrast with studies of Snell \& Duff(1977) who showed that leucine and valine increase the rate of output of alanine in perfused diaphragms from rats. Whether low interconversion of leucine and KIC, observed in the present experiment, occurs in a specific tissue or within many tissues in sheep cannot be determined from whole-body flux values. Studies by Busboom et al. (1984) indicated lower transaminase activity in all tissues examined when compared with non-ruminant tissues.

One additional difference between ruminants and non-ruminants appears to be the presence of an unidentified HPLC peak between $\alpha$-ketomethylvalarate and KIC (see p. 706). Although the identity of this compound is unknown it occurs only in ruminant plasma and may play some role in the low rates of leucine-KIC interconversion observed here in sheep.

In the present study, supplemental energy given in the diet resulted in a decrease in total leucine-C entry $\left(F_{L O}\right)$. This entry represents endogenous protein breakdown as well as absorption of microbial protein. Assuming that supplemental energy in the diet would most likely increase microbial protein synthesis, the observed decrease in total leucine-C entry with HED is very likely due to a suppression of endogenous proteolysis. In addition, this extra energy caused a parallel decrease in the conversion of leucine to KIC by almost $50 \%$. Since leucine concentration increased with the HED (favours leucine to KIC) it would seem that the addition of energy may decrease the transaminase activity.

There are two routes of exit for leucine- $C$ in the proposed model: one from the leucine pool $\left(F_{O L}\right)$ and the other from the KIC pool $\left(F_{O a}\right) . F_{O L}$ can represent protein synthesis, whereas $F_{O a}$ can be considered as an irreversible protein oxidation. In the present experiment, additional energy suppressed tissue protein synthesis and leucine oxidation; most likely this was secondary to a primary decrease in proteolysis. In contrast, Nissen \& Haymond (1981) observed only a decrease in leucine oxidation and proteolysis in $96 \mathrm{~h}$ fasted dogs, with no effect on protein synthesis by this energy restriction. Whether the inhibitory effect on protein metabolism of supplemental energy and the extreme energy restriction of starvation occur through similar mechanisms is unknown.

The mechanism whereby the HED decreases the flux and metabolism of leucine is not clear from these studies. It may be that the animals fed on the LED are in a more 'fasted' 
state than animals fed on the HED, since they have significantly increased FFA, growth hormone and glucagon concentrations while having decreased (although not significant) insulin and glucose levels. Further studies measuring protein metabolism in the fed state should clarify this energy effect on protein metabolism.

Plasma glucagon concentration was higher $(P<0.05)$ in sheep fed on the LED (maintenance level). Additionally, the concentration of glucagon was closely correlated in all treatments with the leucine-C entry (proteolysis) and also with KIC-C exit (oxidation). In rats, glucagon has been shown to increase proteolysis in vitro (Miller, 1976; Triebwasser \& Freedland, 1977). However, studies by Brockman et al. (1975) are not consistent with a catabolic effect of glucagon in ruminants because administration of glucagon did not significantly increase essential amino acid concentration in the blood.

In the studies reported here, the entry of unlabelled KIC was not statistically significantly different from zero. This stems from the fact that $\left[{ }^{14} \mathrm{C}\right]$ leucine and $\left[{ }^{14} \mathrm{C}\right] \mathrm{KIC}$ had nearly equal specific radioactivities. In previous studies (Nissen \& Haymond, 1981) the product specific radioactivity was $30-50 \%$ less than that of leucine. Differences in species may account for some of these inconsistencies as well as differences in analytical techniques between the studies.

It seems that ruminants and simple-stomached animals metabolize leucine in a similar manner, with the exception of leucine-KIC interconversion. This transaminase step seems to be highly regulated inasmuch as supplemental dietary energy decreases leucine-KIC interconversion in spite of elevated plasma leucine concentration favouring this reaction. Further studies concerning the metabolic implications of low leucine-KIC interconversion in ruminants will be necessary to appreciate fully the role of the leucine-KIC cycle in these animals.

This project was supported in part by NIH grant AM 31470 and by the Iowa Agriculture and Home Economics Experimental Station. Dr Piotr Ostaszewski was on the fellowship programme sponsored by the International Atomic Energy Agency in Vienna, Austria. Purified pork insulin and glucagon were kindly provided by Lilly Research Laboratories, Indianapolis, IN. The authors thank Navella Kenagy for her editorial assistance in preparing this manuscript.

\section{REFERENCES}

Ballard, F. J., Filsell, O. H. \& Jarrett, I. G. (1976). Metabolism 25, 415-418.

Bell, A. W., Gardner, J. W., Manson, W. \& Thompson, G. E. (1975). British Journal of Nutrition 33, 207-217.

Brockman, R. P., Bergman, E. N., Joo, P. K. \& Manns, J. G. (1975). American Journal of Physiology 229, $1344-1350$.

Busboom, J. R., Merkel, R. A. S. \& Bergen, W. G. (1984). Journal of Animal Science 59, Suppl. 1, 649.

Coward, B. J. (1979). Ruminant muscle metabolism. PhD thesis, University of Nottingham.

Dean, R. T. (1980). In Biochemistry of Cellular Regulation, pp. 101-122 [G. Ashwell, editor]. Boca Raton, Florida: CRC Press.

Fagan, J. M. \& Tischler, M. E. (1982). Federation Proceedings 41, 866.

Faloona, G. \& Unger, R. (1974). In Methods of Hormone Radioimmunoassay, pp. 287-300 [B. Jaffe and H. Behrman, editors]. New York: Academic Press.

Frick, G. P. \& Goodman, H. M. (1979). Federation Proceedings 38, 947.

Gillim, S. E., Paxton, R., Gook, G. \& Harris, R. A. (1983). Biochemical and Biophysical Research Communications $111,74-81$.

Goldberg, A. L. \& Chang, T. W. (1978). Federation Proceedings 37, 2301.

Haymond, M. W. \& Miles, J. M. (1982), Diabetes 31, 86-89.

Helland, S. J. (1984). Utilization of glucose and sucrose by the weanling pig. PhD dissertation, Iowa State University.

Hughes, W. A. \& Halestrap, A. P. (1981). Biochemical Journal 196, 459-469.

Hutson, S. M., Cree, T. C. \& Harper, A. E. (1978). Journal of Biological Chemistry 253, 8126-8133.

Ichihara, A., Noda, C. \& Ogawa, K. (1973). Advances in Enzyme Regulation 11, 155-166. 
Kramer, G. \& Hardesty, B. (1980). In Cell Biology, vol. 4, pp. 69-105 [L. Goldstein and D. M. Prescott, editors]. New York: Academic Press.

Lindsay, D. B. (1980). Proceedings of the Nutrition Society 39, 53-59.

Lindsay, D. B., Steel, J. W. \& Buttery, P. J. (1977). Proceedings of the Nutrition Society 36, 33 A.

Matthews, D. E., Bier, D. M., Rennie, M. J., Edwards, R. H. T., Halliday, D., Millward, D. J. \& Clugston, G. A. (1981). Science 214, 1129-1131.

Miller, L. L. (1976). Diabetes 25, 865-871.

Nissen, S. \& Haymond, M. W. (1981). American Journal of Physiology 241, E72-E75.

Nissen, S., Van Huysen, C. V. \& Haymond, M. W. (1982). Journal of Chromatography 232, 170-175.

Odyssey, R. (1980). Biochemical Journal 192, 155-163.

Rudiger, H. W., Langenbeck, U. \& Goedde, H. W. (1972). Biochemical Journal 126, 445-456.

Shimizu, S., Inoue, K., Tani, Y. \& Yamada, H. (1979). Analytical Biochemstry 98, 341-345.

Snell, K. \& Duff, D. A. (1977). Biochemical Journal 162, 399-403.

Teleni, E., Annison, E. F., Lindsay, D. B. \& Mackenzie, J. (1983). Proceedings of the Nutrition Society 42, 92 A.

Trenkle, A. (1970). Journal of Nutrition 100, 1323-1330.

Trenkle, A. (1976). Journal of Animal Science 43, 1035-1043.

Triebwasser, K. C. \& Freedland, R. A. (1977). Biochemical and Biophysical Research Communications 76, 1159-1165.

Trinder, P. (1969). Annals of Clinical Biochemistry 6, 24-27.

Veerkamp, J. H. \& Wagenmakers, A. J. M. (1981). Metabolism and Clinical Implications of Branched-chain Amino and Ketoacids, pp. 163-168 [M. Walser and J. R. Williamson, editors]. Amsterdam: Elsevier North-Holland.

Wallace, A. L. C. \& Ferguson, K. A. (1963). Journal of Endocrinology 26, 259-263. 